\title{
Penggunaan Alat Semboyan 21 Malam pada Gerbong Daop 5 Purwokerto
}

\author{
Azhar Hermawan, Sidemus Purwanto Rumaratu, Yunanda P \\ Politeknik Trasnsportasi Darat Indonesia-STTD \\ Email: azhar.hermawan@ptdisttd.ac.id
}

\begin{abstract}
Abstrak
Tujuan penelitian ini adalah untuk menganalisis penggunaan alat semboyan 21 malam pada gerbong Daop 5 Purwokerto. Penelitian ini menggunakan jenis penelitian kualitati dengan pendekatan analsisi deskriptif. Penelitian ini menggunakan beberapa tahapan, diantaranya adalah tahap persiapan, tahap perancangan, tahap perwujudan alat dan tahap pengujian alat. Data dalam penelitian terdiri dari data primer dan data sekunder. Analisis data hasil penelitian menggunakan analisis gangguan semboyan 21 malam gerbong dan analisis kondisi eksisting semboyan 21 malam gerbong. Berasarkan data dan analisis, dapat disimpulkan bahwa: 1) Dari segi indikasi pencahayaan lampu Semboyan 21 malam gerbong yang kurang terang maka diusulkan untuk mengganti lampu yang digunakan sekarang dengan LED karena dari segi pencahayaan yang dihasilkan lebih terang, jelas dan jarak tampak yang lebih jauh; 2) Dengan berbagai macam bentuk, ukuran dan rangkaian lampu Semboyan 21 malam yang ada di lintas Purwokerto - Kutoarjo maka diusulkan untuk memehuni Peratutan Dinas 3 PT.KAI dan spesifikasi teknis semboyan 21 No.054/ST-N.F/RE. agar ada keseragaman di setiap stasiun dan dipo; dan 3) Keterbatasan semboyan 21 dan cadangan semboyan 21 yang kurang memadai disebabkan karena lampu semboyan 21 hanya bergantung pada daya baterai yang digunakan selama perjalanan.
\end{abstract}

Kata Kunci: Penggunaan, Alat Semboyan, Kereta Api, Gerbong.

\begin{abstract}
The purpose of this study was to analyze the use of the 21 night motto on the Daop 5 Purwokerto carriage. This research uses qualitative research with descriptive analysis approach. This study uses several stages, including the preparation stage, the design stage, the tool embodiment stage and the tool testing stage. The data in the study consisted of primary data and secondary data. Analysis of the research data using the analysis of disturbances of the slogan 21 night wagon and analysis of the existing condition of the slogan 21 night carriage. Based on the data and analysis, it can be concluded that: 1) In terms of the lighting indications of the 21 night carriage motto, which is not bright enough, it is proposed to replace the lamps currently in use with LEDs because the lighting produced is brighter, clearer and has a longer visible distance; 2) With various shapes, sizes and series of lights for the 21 night motto that exist on the Purwokerto - Kutoarjo route, it is proposed to comply with the Regulations of the 3rd Office of PT KAI and the technical specifications of the slogan 21 No.054/ST-N.F/RE. so that there is uniformity at every station and depot; and 3) the limitation of the slogan 21 and the insufficient reserve of the slogan 21 due to the lamp 21 only depending on the battery power used during the trip.
\end{abstract}


Keywords: Usage, Motto, Train, Carriage.

\section{A. PENDAHULUAN}

Perkeretaapian diselenggarakan dengan tujuan untuk memperlancar perpindahan orang/barang secara masal dengan selamat, aman, nyaman, cepat, lancar, tepat, tertib, teratur dan efisien. Kereta api adalah sarana perkeretaapian dengan tenaga gerak, yang sedang bergerak di jalan rel terkait dengan perjalanan kereta api (Rumaratu, 2020). Baik berjalan sendiri maupun dirangkaikan dengan sarana perkeretaapian lainnya. Sehingga kereta api merupakan salah satu alat transportasi yang memiliki karakteristik dan keunggulan terutama dalam kemampuannya untuk mengangkut penumpang maupun barang secara masal, hemat energi, hemat ruang, dan mempunyai faktor keamanan yang tinggi dan tingkat pencemaran yang rendah (Puruhita et al.,2021).

Untuk pengoperasian dan pengamanan perjalanan KA terdapat Peraturan Dinas 3 mengenai Semboyan. Semboyan adalah pesan yang bermakna bagi petugas yang berkaitan dengan perjalanan KA sebagai: perintah atau larangan, yang ditunjukkan/diperagakan melalui orang atau alat berupa wujud, warna, cahaya atau bunyi, meliputi: isyarat, sinyal dan tanda. Semboyan pada Peraturan Dinas 3 terdapat semboyan yang mengatur pada siang hari dan malam hari. Pada waktu malam hari, waktu kabut atau halimun, hujan lebat, dan lain-lain sehingga cuaca menjadi gelap, semboyan malam hari harus dipasang dan diperlihatkan Lentera (Ihsanto \& Ramadhan, 2014).

Kondisi saat ini pada sarana di lintas Purwokerto-Kutoarjo pada umumnya sudah baik, namun masih terdapat beberapa fasilitas operasi yang masih belum ada standar maupun spesifikasinya yaitu pada peralatan persinyalan. Dengan melihat kemajuan dari perkeretaapian Indonesia, tentu semua komponen yang merupakan dari satu kesatuan system harus saling terpadu dan koneksi agar semua komponen dapat terjamin keamanan, terutama untuk kepuasan pelanggan jasa kereta api (Rozaq et al.,2019).

Dari data gangguan perbaikan semboyan 21 pada gerbong dan hasil survei yang telah dilakukan penulis pada saat Praktek Kerja Lapangan di Daop 5 Purwokerto lintas PurwokertoKutoarjo, penulis menemukan beberapa masalah yang terdapat beberapa indikasi pencahayaan lampu semboyan 21 malam gerbong yang kurang terang maupun matinya cahaya lampu semboyan 21 malam dalam perjalanan KA dan mengakibatkan KA tersebut Berhenti Luar Biasa (BLB), serta keterbatasan baterai semboyan 21 malam kurang memadai untuk menyampaikan semboyan malam kepada masinis, PJL, dan PAP/PPKA dan yang perlu diperbaiki untuk meningkatkan fungsi semboyan malam.

Lampu Semboyan 21 malam pada gerbong adalah lampu tanda akhiran rangakaian KA barang yang beroprasi. Lampu Semboyan 21 malam pada gerbong yang dipasangkan pada KA paling akhir merupakan seperangkat lampu/alat yang digunakan untuk menyampaikan pesan yang bermakna bagi Masinis, PJL, dan PPKA/PAP yang berkaitan dengan perjalanan KA sebagai isyarat bahwa rangkaian KA dalam keadaan lengkap. Di wilayah daerah operasi 5 Purwokerto khususnya di lintas Purwokerto - Kutoarjo terdapat lampu Semboyan 21 malam pada gerbong yang rangkaian lampunya beberapa stasiun berbeda-beda dalam memodifikasi lampu semboyan 21 malam, sehingga hasil pencahayaan yang dihasilkan lampu semboyan 21 malam tersebut berbeda-beda (Aghastya et al.,2019). Pencahayaan yang berbeda-beda disebabkan dari bentuk maupun jenis lampu yang digunakan berbeda-beda. Pada lampu semboyan 21 malam banyak perbedaan yang terdiri dari baterai, lampu, rangkaian, kaca(mika akrilik) tersebut berbeda (Putra, 2017). Disini terdapat pencahayaan yang kurang terang yang di berikan untuk Masinis, PJL, dan PPKA/PAP. 


\section{B. TINJAUAN PUSTAKA}

\section{Aspek Legalitas}

Untuk mendukung penyusunan Kertas Kerja Wajib ini, maka perlu di kemukakan hal hal atau teori berkaitan dengan permasalahan dan ruang lingkup pembahasan sebagai landasan dalam penyusunan penelitian ini.

Undang - Undang No 23 tahun 2007 tentang perkeretaapian yang digunakan terdiri dari: 1) Pasal 1 ayat 1 . Perkeretaapian adalah satu kesatuan sistem yang terdiri atas prasarana, sarana, dan sumber daya manusia, serta norma, kriteria, persyaratan, dan prosedur untuk penyelenggaraan transportasi kereta api; 2) Pasal 1 ayat 2. Kereta api adalah sarana perkeretaapian dengan tenaga gerak, baik berjalan sendiri maupun dirangkaikan dengan sarana perkeretaapian lainnya, yang akan ataupun sedang bergerak di jalan rel yang terkait dengan perjalanan kereta api; 3) Pasal 1 ayat 8. Fasilitas operasi kereta api adalah segala fasilitas yang diperlukan agar kereta api dapat dioperasikan; 4) Pasal 1 ayat 9. Sarana perkeretaapian adalah kendaraan yang dapat bergerak di jalan rel; 5) Pasal 1 ayat 11. Fasilitas penunjang kereta api adalah segala sesuatu yang melengkapi penyelenggaraan angkutan kereta api yang dapat memberikan kemudahan, kenyamanan, dan keselamatan bagi pengguna jasa kereta api; 6) Pasal 1 ayat 14. Angkutan kereta api adalah kegiatan pemindahan orang atau barang dari satu tempat ke tempat lain dengan menggunakan kereta api; dan 7) Pasal 27. Pengoperasian sarana perkeretaapian umum sebagaimana dimaksud dalam Pasal 25 huruf $b$ wajib memenuhi standar kelaikan operasi sarana perkeretaapian.

Selanjutnya, Peraturan Pemerintah No 72 tahun 2009 tentang lalu lintas kereta api, yaitu: 1) Pasal 1 ayat 4. Lalu lintas kereta api adalah gerak sarana perkeretaapian di jalan rel; 2) Pasal 1 ayat 4. Petugas pengatur perjalanan kereta api adalah orang yang melakukan pengaturan perjalanan kereta api dalam batas stasiun operasi atau beberapa stasiun operasi dalam wilayah pengaturannya; 3) Pasal 1 ayat 4 . Stasiun operasi adalah stasiun kereta api yang memiliki fasilitas untuk bersilang, menyusul kereta api dan/atau langsir, dan dapat berfungsi untuk naik/turun penunmpang dan/atau bongkar muat barang; 4) Pasal 1 ayat 4. Pengaturan perjalanan kereta api dilakukan dengan semboyan berupa: Isyarat dari petugas pengatur perjalanan kereta api, Sinyal, Tanda, atau Marka.

\section{Aspek Teoritis}

Solar Cell adalah suatu perangkat atau komponen yang dapat mengubah energi cahaya matahari menjadi energi listrik dengan menggunakan prinsip efek Photovoltaic. Yang dimaksud dengan Efek Photovoltaic adalah suatu fenomena dimana munculnya tegangan listrik karena adanya hubungan atau kontak dua elektroda yang dihubungkan dengan sistem padatan atau cairan saat mendapatkan energi cahaya (Aisyah et al.,2017). Oleh karena itu, Sel Surya atau Solar Cell sering disebut juga dengan Sel Photovoltaic (PV). Efek Photovoltaic ini ditemukan oleh Henri Becquerel pada tahun 1839. Energi matahari merupakan sumber energi yang paling menjanjikan mengingat sifatnya yang berkelanjutan (renewable) serta jumlahnya yang sangat melimpah (Kurniawan et al.,2021). Matahari merupakan sumber energi yang diharapkan dapat mengatasi permasalahan kebutuhan energi masa depan setelah berbagai sumber energi konvensional berkurang jumlahnya. Selain itu pemanfatan sinar matahari melalui potovoltaik ini sudah terbukti sangat ramah lingkungan (Rozaq et al.,2021).

Salah satu keutamaan solar cell yang sangat didambakan oleh semua negara di dunia adalah ramah lingkungan dan sama sekali tidak menimbulkan polusi. Berbeda jauh dengan bahan-bahan sumber energi yang lain, seperti batu bara dan bahan bakar dari fosil yang 
menimbulkan banyak polusi, baik pulusi udara dan air (Ma'ruf et al.,2019). Tentunya solar cell ini sangat membantu mengisi energi ke baterai selama perjalananan Kerera Api.

Selanjutnya, adalah papan PCB. Pengertian PCB (Printed Circuit Board) dan Jenis-jenis PCB-PCB adalah singkatan dari Printed Circuit Board yang dalam bahasa Indonesia sering diterjemahkan menjadi Papan Rangkaian Cetak atau Papan Sirkuit Cetak. Seperti namanya yaitu Papan Rangkaian Tercetak (Printed Circuit Board), PCB adalah Papan yang digunakan untuk Papan PCB dapat digambarkan sesuai dengan rangkian elektronika yan kita inginkan. Keunggulan dari papa PCB yaitu lokasi komponen yang tetap, dapat menyederhanakan proses identifikasi dan perawatan peralatan dan sistem elektronik dan juga hal ini tentunya tahan akan tekan maupun getaran selama perjalanan Kereta Api (Ashari et al.,2020).

Lampu LED, yaitu produk diode pancaran cahaya (LED) yang disusun menjadi sebuah lampu. Lampu LED memiliki usia pakai dan efisiensi listrik beberapa kali lipat lebih balik daripada lampu pijar dan tetap jauh lebih efisien daripada lampu neon, beberapa chip bahkan dapat menghasilkan lebih dari 300 lumen per watt. Lampu LED hanya butuh energi sebesar 10\% dari energi yang dibutuhkan lampu pijar (Munang et al.,2016). Tidak seperti lampu pijar dan lampu neon, lampu LED akan menghasilkan terang sepenuhnya tanpa perlu waktu pemanasan (warm-up) Lampu LED terbuat dari plastik dan diode semikonduktor yang dapat menyala apabila dialiri tegangan listrik rendah (sekitar 1,5 volt DC). Lampu LED tidak seperti lampu pijar dan neon, LED mempunyai kecenderungan polarisasi. Chip LED mempunyai kutub positif dan negatif, dan hanya akan menyala bila diberikan arus maju. Ini dikarenakan LED terbuat dari bahan semikonduktor yang hanya akan mengizinkan arus listrik mengalir ke satu arah sebaliknya. Bila LED diberikan arus terbalik, hanya aka nada sedikit arus yang melewati chip LED. Ini menyebabkan chip LED tidak akan mengeluarkan emisi cahaya. Chip LED pada umumnya mempunyai tegangan rusak yang relative rendah. Bila diberikan tegangan beberapa volt ke arah terbalik, biasanya sifat isolator searah LED akan jebol menyebabkan arus dapat mengalir ke arah sebaliknya (Farhan, 2021).

Modul cas ini dapat digunakan untuk mengecas 1 batrei Lithium atau beberapa batere Lithium yang dihubungkan secara paralel. Kelebihan modul ini menggunakan charging chip TP4056 yang canggih, dengan rangkaian elektronik yang sederhana, mencas dengan akurasi tinggi, diproduksi dengan mesin otomatis dan dapat mengubah arus cas dari $100 \mathrm{~mA} \mathrm{~s} / \mathrm{d}$ $1000 \mathrm{~mA}$ hanya dengan mengganti nilai resistor pada modul. Dipakai untuk mengecas battery lithium dengan kemampuan pengecasan dari 30mA sampai dengan $1000 \mathrm{~mA}$ yang dapat di adjust/di setel, untuk defaul pabrikan sudah di set ke 1000mA / 1A. Modul USB booster 5V ini berperan untuk menyetabilkan tegangan keluaran yang dibuat oleh panel surya diatas. biasanya dapat hasilkan tegangan stabil $5 \mathrm{~V}$ dengan input tegangan pada $1-5 \mathrm{~V}$. Berarti ketika tegangan dari panel surya turun modul ini tetaplah dapat hasilkan tegangan yang cukup untuk dapat isi ulang piranti yang Kamu punyai (Api, 2020). Output dari modul usb booster ini yaitu konektor female usb, hingga dengan kabel usb to mikro/mini usb Kamu dapat segera menghubungkan ke piranti yang ingin di isi ulang.

\section{METODE}

Penelitian ini menggunakan jenis penelitian kualitati dengan pendekatan analsisi deskriptif. Penelitian ini menggunakan beberapa tahapan, diantaranya adalah tahap persiapan, tahap perancangan, tahap perwujudan alat dan tahap pengujian alat. Data dalam penelitian terdiri dari data primer dan data sekunder. Data primer diperoloeh dari data kondisi existing lampu semboyan 21 malam pada gerbong di lintas Purwokerto-Kutoarjo. Sedangkan data sekunder diperoleh dari data spesifikasi semboyan 21 malam, GAPEKA 2019, serta data gangguan perbaikan semboyan 21 Gerbong 2019. Analisis data hasil penelitian menggunakan analisis gangguan semboyan 21 malam gerbong dan analisis kondisi eksisting semboyan 21 malam gerbong. 


\section{HASIL DAN PEMBAHASAN}

\section{Kondisi Eksisting}

Kondisi saat ini pada sarana di lintas Purwokerto - Kutoarjo pada umumnya sudah baik, namun masih terdapat beberapa fasilitas operasi yang masih belum ada standar maupun spesifikasinya yaitu pada peralatan persinyalan. Dengan melihat kemajuan dari perkeretaapian Indonesia, tentu semua komponen yang merupakan dari satu kesatuan system harus saling terpadu dan koneksi agar semua komponen dapat terjamin keamanan, terutama untuk kepuasan pelanggan jasa kereta api. Dari data gangguan perbaikan Semboyan 21 gerbong 2019 dan hasil survei yang telah dilakukan penulis pada saat Praktek Kerja Lapangan di Daop 5 Purwokerto lintas Purwokerto - Kutoarjo, penulis menemukan beberapa masalah yang terdapat di stasiun maupun di lintas dengan adanya lampu Semboyan 21 malam pada gerbong yang cahayanya kurang memadai dan mati dalam perjalanan kereta api serta keterbatasan cadangan semboyan 21 yang hanya pada stasiun besar.

Lampu Semboyan 21 malam pada gerbong adalah lampu tanda akhiran rangakaian KA barang yang beroprasi. Lampu Semboyan 21 malam pada gerbong yang dipasangkan pada KA paling akhir merupakan seperangkat lampu/alat yang digunakan untuk menyampaikan pesan yang bermakna bagi Masinis, PJL, dan PPKA/PAP yang berkaitan dengan perjalanan KA sebagai isyarat bahwa rangkaian KA dalam keadaan lengkap.Di wilayah daerah operasi 5 Purwokerto khususnya di lintas Purwokerto - Kutoarjo terdapat lampu Semboyan 21 malam pada gerbong yang rangkaian lampunya beberapa stasiun berbeda-beda dalam memodifikasi lampu semboyan 21 malam, sehingga hasil pencahayaan yang dihasilkan lampu semboyan 21 malam tersebut berbeda-beda (Njatrinjani et al.,2016). Pencahayaan yang berbeda-beda disebabkan dari bentuk maupun jenis lampu yang digunakan berbeda-beda. Pada lampu semboyan 21 malam banyak perbedaan yang terdiri dari bentuk, ukuran, rangkaian, kaca (mika akrilik) tersebut berbeda. Disini terdapat pencahayaan yang kurang terang yang di berikan untuk Masinis, PJL, dan PPKA/PAP. Dari data-data yang telah dikumpulkan baik data sekunder maupun data primer, diolah dan dilakukan analisis data. Data-data tersebut akan dianalisis untuk merancang lampu semboyan 21 malam pada gerbong yang dapat digunakan secara optimal dengan pencahayaan yang tegas (Fadhilah, 2014).

Berdasarkan data di atas yang diperoleh dari GAPEKA (Grafik Perjalanan Kereta Api) tahun 2019 terdapat 27 KA barang yang melintasi lintas Purwokerto - Kurtoarjo, dari jumlah KA barang yang melintas di lintas Purwokerto - Kurtoarjo adapun KA barang yang Behenti Luar Biasa (BLB) karena lampu semboyan 21 malam gangguan/mati dalam perjalanan KA dan harus melakukan perbaikan atau penggantian lampu semboyan 21 malam cadangan yang ada pada stasiun tertentu.

Berikut adalah daftar gangguan perbaikan Semboyan 21 malam gerbong lintas Purwokerto - Kutoarjo:

Tabel 1. Daftar gangguan perbaikan Semboyan 21 malam gerbong 2019

\begin{tabular}{|c|c|c|c|c|c|c|c|c|}
\hline No. & Dinas & Penyebab & Tanggal & Lokasi & No KA & Nama KA & Relasi & Andil \\
\hline \multirow{3}{*}{1} & \multirow{3}{*}{ Sarana } & \multirow{3}{*}{$\begin{array}{c}(41009) \\
\text { Perbaikan } \\
\text { Semboyan } 21 \\
\text { Malam } \\
\text { Gerbong }\end{array}$} & $10 / 18 / 2019$ & $\begin{array}{c}\text { Sta. } \\
\text { Kutoarjo }\end{array}$ & $2748 \mathrm{~F}$ & $\begin{array}{l}\text { Karsolo } \\
\text { Service }\end{array}$ & Krl - Slo & 5 menit \\
\hline & & & $12 / 1 / 2019$ & $\begin{array}{c}\text { Sta. } \\
\text { Kutoarjo }\end{array}$ & $2763 \mathrm{~F}$ & $\begin{array}{l}\text { Karsolo } \\
\text { Service }\end{array}$ & Krl - Slo & 7 menit \\
\hline & & & $12 / 15 / 2019$ & $\begin{array}{c}\text { Sta. } \\
\text { Kutoarjo }\end{array}$ & $2763 \mathrm{~F}$ & $\begin{array}{l}\text { Karsolo } \\
\text { Service }\end{array}$ & Krl - Slo & 2 menit \\
\hline
\end{tabular}

Sumber: data diolah 


\section{Analisis Permasalahan}

Analisis permasalahan berdasarkan dari data-data yang telah didapatkan baik data primer maupun data sekunder untuk membuat perangcangan lampu semboyan 21 malam pada gerbong. Dari data gangguan perbaikan Semboyan 21 gerbong 2019 dan hasil survei yang telah dilakukan penulis pada saat Praktek Kerja Lapangan di Daop 5 Purwokerto lintas Purwokerto - Kutoarjo, penulis menemukan beberapa masalah yang terdapat di stasiun maupun di lintas dengan adanya lampu Semboyan 21 malam pada gerbong yang cahayanya kurang memadai dan mati dalam perjalanan kereta api. rangkaian lampunya beberapa stasiun berbeda-beda dalam memodifikasi lampu semboyan 21 malam, sehingga hasil pencahayaan yang dihasilkan lampu semboyan 21 malam tersebut berbeda-beda (Mahmudi, 2019). Pencahayaan yang berbeda-beda disebabkan dari bentuk maupun jenis lampu yang digunakan berbeda-beda. Pada lampu semboyan 21 malam banyak perbedaan yang terdiri dari baterai, lampu, rangkaian, kaca(mika akrilik) tersebut berbeda. Disini terdapat pencahayaan yang kurang terang yang di berikan untuk Masinis, PJL, dan PPKA/PAP.

Indikasi Pencahayaan Pada Lampu Semboyan 21 Malam Gerbong Pencahayaan yang berbeda-beda disebabkan dari bentuk maupun jenis lampu yang digunakan berbeda-beda. Pada lampu semboyan 21 malam banyak perbedaan yang terdiri dari baterai, lampu, rangkaian, kaca(mika akrilik) tersebut berbeda-beda.

Ketika lampu dinyalakan warna cahaya lampu yang dihasilkan menajdi berwarna kuning. Lampu ini menggunakan lampu LED biasa yang berwana putih dan kaca atau mika di beri warna merah dan hijau agar dapat menghasilkan cahaya warna hijau dan merah yang sumber energinya dari baterai, sehingga cahaya yang dihasilkan tergantung pada daya baterai yang ada.

Gambar 1. Pencahayaan dari Semboyan 21

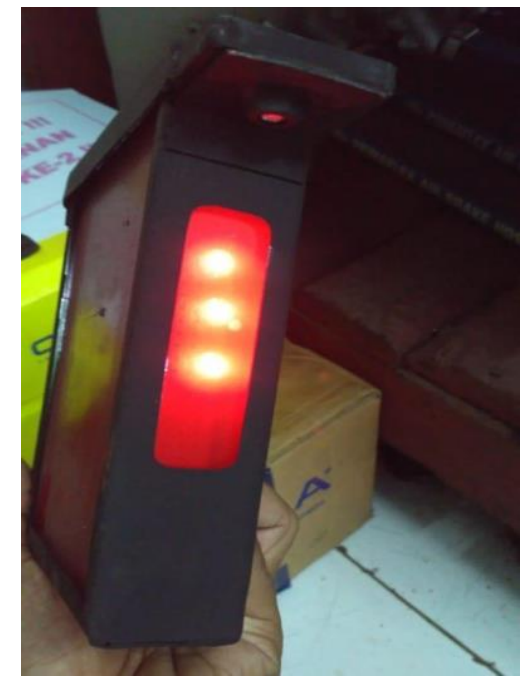

Sumber: data diolah

Terdapat Kondisi mika akrilik yang digunakan sebagai pewarna cahaya yang sudah kurang baik atau sudah pudar.hal ini akan mengakibatkan isyarat warna cahaya yang dihasilkan tidak sesuai dengan standar spersifikasi lampu semboyan 21 malam dalam aturan perkeretaapian. Memasangkan lampu semboyan 21 pada dudukannya diakhir rangkaian KA barang (Sukmawati, 2021). Ketika KA dalam perjalanan KA barang mengalami peralihan waktu dari siang ke malam, KA barang tersebut harus dipasangkan semboyan 21 malam dari stasiun awal dan harus dinyalakan. proses pengorasian lampu semboyan 21 malam hanya bisa mengchager batrei pada stasiun sebelum perjalan KA dan hal ini dilakukan setiap kali dan tidak dapat mengetahui volume batrei yang sudah terisi. Setelah itu dipasangkan pada rangkaian KA paling akhir yang akan berangkat. Hal ini tentu akan mempersulit penggunaan lampu semboyan 21 malam. 
Dalam pengoperasian perjalanan KA barang daop Purwokerto memiliki tiga stasiun besar yaitu: 1) Stasiun Purwokerto (KDK/scowing); 2) Stasiun Kroya (PUS Kroya); dan 3) Stasiun Kutoarjo (KDK/scowing). DAOP 5 Purwokerto lintas Purwokerto - Kutoarjo hanya ada 3 stasiun yang memiliki unit sarana untuk mengatasi gangguan perbaikan semboyan 21 malam gerbong yang mempunyai cadangan semboyan 21 hal ini tentunya sangat terbatas ketersedian cadangan lampu semboyan 21 pada beberapa stasiun.

Masalah lain yang terjadi adalah lampu semboyan 21 malam menggunakan baterai yang berkapasitas $3800 \mathrm{mAh}$ yang dapat menyuplai listrik pada beban lampu sekita 3-4 jam, baterai ini merupakan sumber energi dari cahaya lampu tersebut. Baterai hanya dapat dicharger pada stasiun, batrerai akan dilepas dari rangkaian lampu semboyan 21 malam dan di charger pada stasiun hingga penuh dan dipasangkan lagi pada rangkaian lampu semboyan 21 malam.

Keterbatasan semboyan 21 yang kurang memadai dalam perjalanan KA untuk menyampaikan semboyan malam kepada masinis, PPKA/PAP, dan PJL. Hal dikarenakan terbatasnya daya pada baterai dan cadangan semboyan 21 yang hanya ada pada stasiun kelas besar selama perjalanan KA. Tentunya hal ini dapat menyebabkan matinya cahaya lampu semboyan 21 malam disaat perjalan KA barang dan dapat menyebabkan KA tersebut Berhenti Luar Biasa (BLB). Tentunya hal ini sangat mengganggu pengoprasian perjalanan KA lainya.

Dari data gangguan semboyan 21 dan kondisi existing lampu Semboyan 21 malam gerbong yang ada di lintas Purwokerto - Kutoarjo dapat diketahui kekurangan yang terdapat pada lampu Semboyan 21 malam gerbong. Dibawah ini adalah daftar kekurangan dari lampu Semboyan 21 malam gerbong di lintas Purwokerto - Kutoarjo: 1) Sumber energi listrik hanya dari batrei selama perjalanan KA; 2) Menggunakan lampu senter kecil; 3) Pencahayaan yang kurang terang; 4) Jarak padang cahaya yang dihasilkan kurang memadai; 5) Menggunakan $\mathrm{kaca} / \mathrm{mika}$ berwarna sebagai pewarna cahaya; 6) Warna cahaya yang dihasilkan tidak terlalu sesuai; 7) Menggunakan kaca/mika dilapisi sekotlet warna; 8) Cahaya tidak fokus; 9) Charger batrei hanya pada stasiun; dan 10) Terdapat baterai yang dayanya tidak cukup semalam perjalanan KA dan mengakibatkan matinya lampu semboyan 21 dan BLB KA tersebut.

\section{Pemecahan Masalah}

Dari banyaknya perbedaan jenis rangkaian Lampu Semboyan 21 malam gerbong dan terdapat indikasi pencahayaan yang kurang terang, maka untuk memecahkan masalah tersebut digunakan berbagai solusi agar Lampu Semboyan 21 malam yang dioprasikan maksimal, indikasi cahaya yang terang dan mobilitas yang memadai untuk menyampaikan semboyan malam kepada Masinis,PJL, dan PPKA/PAP. Di bawah ini adalah beberapa solusi yang digunakan untuk memperbaiki Lampu Semboyan 21 malam, antara lain:

Menggunakan Light Emitting Diode (LED). Lampu LED terbuat dari plastik dan diode semikonduktor yang dapat menyala apabila dialiri tegangan listrik rendah (sekitar 1,5 volt DC). Lampu LED tidak seperti lampu pijar dan neon, LED mempunyai kecenderungan polarisasi. Chip LED mempunyai kutub positif dan negatif, dan hanya akan menyala bila diberikan arus maju. Ini dikarenakan LED terbuat dari bahan semikonduktor yang hanya akan mengizinkan arus listrik mengalir ke satu arah sebaliknya. Bila LED diberikan arus terbalik, hanya aka nada sedikit arus yang melewati chip LED. Ini menyebabkan chip LED tidak akan mengeluarkan emisi cahaya. Chip LED pada umumnya mempunyai tegangan rusak yang relative rendah. Bila diberikan tegangan beberapa volt ke arah terbalik, biasanya sifat isolator searah LED akan jebol menyebabkan arus dapat mengalir ke arah sebaliknya.

Dibawah ini adalah tabel dari perbedaan kondisi eksisting dan kondisi yang diusulkan untuk dapat dijadikan sebagai acuan untuk mengganti/menggunakan peralatan yang diusulkan dengan melihat pertimbangan seperti yang tertera dibawah ini: 
Tabel 2. Perbedaan kondisi eksisting dan usulan pada lampu S 21

\begin{tabular}{|c|c|c|}
\hline No & Existing & Usulan \\
\hline 1 & $\begin{array}{l}\begin{array}{l}\text { Beberapa S21 yang tidak } \\
\text { spesifikasinya }\end{array} \\
\end{array}$ & Sumber cahaya dari LED \\
\hline 2 & Sumber arus hanya dari baterai & Cahaya lebih terang \\
\hline 3 & $\begin{array}{l}\text { Menggunakan kaca pewarna/skotlet sebagai pengubah } \\
\text { warna cahaya }\end{array}$ & $\begin{array}{l}\text { Jarak pandang cahaya } 200 \\
\text { meter }\end{array}$ \\
\hline 4 & Cahaya tidak fokus & Bahan Akrilik \\
\hline 5 & Pencahayaan yang kurang terang & $\begin{array}{l}\text { Sumber listrik dari baterai } \\
\text { dan solarcell }\end{array}$ \\
\hline 6 & Jarak pandang cahaya kurang memadai & $\begin{array}{l}\text { Baterai dapat di charge } \\
\text { dengan mudah dan efisien }\end{array}$ \\
\hline 7 & Menggunakan kaca mika yang kondisinya kurang baik & Lampu indikasi charge \\
\hline 8 & Cara charger kurang efektif & $\begin{array}{l}\text { Lampu indikasi daya batrei } \\
\text { yang terisi }\end{array}$ \\
\hline 9 & Tidak ada lampu indikasi daya baterai yang terisi & Cahaya lebih fokus \\
\hline 10 & Kabel charger kurang efektif & Ketahanan baterai 12 jam \\
\hline 11 & Menggunakan baterai yang dayanya kecil & $\begin{array}{llr}\begin{array}{l}\text { Dapat } \\
\text { selama }\end{array} & \begin{array}{l}\text { mengisi } \\
\text { solarcell }\end{array} & \text { baterai } \\
\text { solanan } & \text { dari } \\
\end{array}$ \\
\hline
\end{tabular}

Sumber: data diolah

Lampu pijar lebih murah tetapi juga kurang efisien dibandingkan LED. Lampu TL lebih efisien daripada lampu pijar, tapi butuh tempat besar dan mudah pecah. LED mempunyai beberapa keunggulan dibandingkan dengan lampu pijar, LED tidak memerlukan gas untuk menghasilkan cahaya. Selain itu bentuk dari LED yang sederhana, kecil dan kompak memudahkan penempatannya. Dalam hal efisiensi, LED memiliki keunggulan yaitu hanya sedikit menghasilkan panas, sehingga porsi terbesar dari energy listrik yang ada digunakan untuk menghasilkan cahaya dan membuatnya jauh lebih efisien. Keunggulan menggunakan lampu LED: 1) Waktu hidup lampu LED yang tahan lama; 2) Efisiensi energy; 3) Ramah lingkungan; 4) Kualitas durable (komponen yang kokoh); 5) Nol emisi UV; 6) Fleksibilitas desain; 7) Dapat beroperasi di suhu dingin atau sangat panas; 8) Memfokuskan cahaya; DAN 9) Pencahayaan instan dan seringnya di mati-hidupkan, Low-voltage.

\section{E. KESIMPULAN}

Berasarkan data dan analisis, dapat disimpulkan bahwa: 1) Dari segi indikasi pencahayaan lampu Semboyan 21 malam gerbong yang kurang terang maka diusulkan untuk mengganti lampu yang digunakan sekarang dengan LED karena dari segi pencahayaan yang dihasilkan lebih terang, jelas dan jarak tampak yang lebih jauh; 2) Dengan berbagai macam bentuk, ukuran dan rangkaian lampu Semboyan 21 malam yang ada di lintas Purwokerto Kutoarjo maka diusulkan untuk memehuni Peratutan Dinas 3 PT.KAI dan spesifikasi teknis semboyan 21 No.054/ST-N.F/RE. agar ada keseragaman di setiap stasiun dan dipo; dan 3) Keterbatasan semboyan 21 dan cadangan semboyan 21 yang kurang memadai disebabkan karena lampu semboyan 21 hanya bergantung pada daya baterai yang digunakan selama 
perjalanan dan cadangan semboyan 21 hanya ada pada stasiun besar, dari kondisi tersebut penulis mengajukan usulan untuk menggunakan Lampu Semboyan 21 usulan.

\section{DAFTAR PUSTAKA}

Aghastya, A., Jamaludin, J., Wirawan, W. A., \& Rozaq, F. (2019). Peningkatan Keselamatan Masyarakat Dalam Memahami Rambu Lalulintas di Perlintasan Sebidang (studi kasus di SMKN 1 Wonoasri, Madiun). Prosiding SENIATI, 331-334.

Aisyah, S., Winantoko, S., \& Wibisono, A. (2017). Prototipe Pemindah Wesel Kereta Menggunakan RFID Berbasis Arduino UNO. AUTOCRACY: Jurnal Otomasi, Kendali, dan Aplikasi Industri, 4(02), 115-121.

Api, G. L. K. (2020). Perkembangan Teknologi Tenaga Penggerak Kereta Api Jalur Rangkasbitung-Labuan Tahun 1970-1980. Jurnal Kala Manca, 8(1).

Ashari, M. Z. A. H., Jamsari, E. A., Safian, N. L., \& Safiai, M. H. (2020). Sejarah Pembangunan Teknologi Ketenteraan Kerajaan Banu Marin Di Al-Maghrib (History of Military Technology Development of the Marinid Kingdom in the Maghreb). Journal of Al-Tamaddun, 15(2), 147-161.

Fadhilah, A. (2014). Budaya pangan anak singkong dalam himpitan modernisasi pangan: eksistensi tradisi kuliner rasi (beras singkong) komunitas kampung adat Cireundeu Leuwi Gajah Cimahi Selatan Jawa Barat. Buletin Al-Turas, 20(1), 13-30.

Farhan, M. H. (2021). Desain Prototype Penggerak Sinyal Mekanik dan Wesel Stasiun Kereta Api Kecil Berbasis PLC (Doctoral dissertation, Universitas Muhammadiyah Malang).

Ihsanto, E., \& Ramadhan, F. (2014). Perancangan Simulasi Sistem Pemantauan Pintu Perlintasan Kereta Api Berbasis Arduino. Jurnal Teknologi Elektro, 5(2), 141935.

Kurniawan, M. A., Puspitasari, A., Prasetya, H. W., Arifianto, T., \& Utomo, I. S. (2021). Sosialisasi Keselamatan Perkeretaapian Di SDN Ngujung II Magetan. Madiun Spoor: Jurnal Pengabdian Masyarakat, 1(1).

Ma'ruf, M. F., Ramdhani, M., \& Sugiana, A. (2019). Perancangan Tata Letak Pcb Dengan Metode Grounding Untuk Modul Sensor Gy-521 Sebagai Alat Deteksi Kereta Api. eProceedings of Engineering, 6(2).

Mahmudi, I. (2019). Studi Keselamatan Dan Keamanan Pada Perlintasan Sebidang Jalur Kereta Api Dengan Jalan Umum (Studi kasus perlintasan kereta api jalan kenjeran kota surabaya) (Doctoral dissertation, Universitas Narotama).

Munang, A., Faisal, R. M., \& Mansur, A. (2016). Evaluasi dan Perencanaan Mitigasi Resiko Proyek Pembangunan Jalur Ganda Kereta Api Semarang-Bojonegoro. Teknoin, 22(2).

Munang, A., Faisal, R. M., \& Mansur, A. (2018). Manajamen risiko keselamatan dan kesehatan kerja (k3) proyek pembangunan jalur ganda kereta API. Applied Industrial Engineering Journal, 2(1), 8-15.

Njatrijani, R., Mahmudah, S., \& Riyadi, A. (2016). Tanggung Jawab PT Kereta Api Indonesia (Persero) sebagai Perusahaan Jasa Pengangkutan terhadap Keselamatan Penumpang Kereta di Perlintasan Sebidang. Diponegoro Law Review, 5(2), 19012.

Pambudy, A. H., Yadi, Y. H., \& Susihono, W. (2014). Analisis Display Sinyal Kereta Api di Stasiun Langen. Jurnal Teknik Industri Untirta, 2(1).

Prawiradiredja, S., \& Maharindra Muhammad, A. Corporate Value: Persona pada Company Profile PT. Kereta Api Indonesia. Jurnal Komunikasi Profesional.

Puruhita, H. W., Lestari, S. M., Agustriana, T. M., Aghastya, A., \& Triwijaya, S. (2021). Pengenalan Keselamatan Perkeretaapian sejak Dini (Lokasi: SD Negeri Tebon 1 Magetan). Madiun Spoor: Jurnal Pengabdian Masyarakat, 1(1).

Putra, R. (2017). Analisis Beban Kerja Petugas Jaga Lintasan Dengan Menggunakan Metode Defence Research Agency Workload Scale (DRAWS) Di Pos Jaga 165A Jl. Laswi 
Bandung PT. Kereta Api Indonesia (PERSERO) DAOP 2 Bandung (Doctoral dissertation, Fakultas Teknik).

Rozaq, F., Adi, W. T., Wirawan, W. A., \& Prativi, A. (2019). Peningkatan Kompetensi Penjaga Pintu Perlintasan Sebidang Transportasi Perkeretaapian Di Kota Padang Sumatera Barat Melalui Program Pemberdayaan Masyarakat. Prosiding SENIATI, 303-306.

Rozaq, F., Wirawan, W. A., Rachman, N. F., Handoko, H., \& Zulkarnaen, A. (2021). Sosialisasi Keselamatan Perkeretaapian untuk Meningkatan Peran Masyarakat Tertib Berlalu Lintas di Perlintasan Sebidang. Madiun Spoor: Jurnal Pengabdian Masyarakat, 1(1).

Rumaratu, S. P. (2020). Penggunaan Alat Semboyan 21 Malam Pada Gerbong Daop 5 Purwokerto (Doctoral dissertation, POLITEKNIK TRANSPORTASI DARAT INDONESIA-STTD).

Sukmawati, C. S. R. (2021). Perlindungan Hukum bagi Pengguna Jasa Transportasi Kereta Api pada Masa Pandemi Covid-19 (Doctoral dissertation, UPN Jawa Timur). 